\title{
The Trade Impact of Enhanced Multimodal Connectivity in the Asia-Pacific Region
}

\author{
Ben Shepherd \\ Developing Trade Consultants Ltd \\ Ramonette B. Serafica \\ Akhmad Bayhaqi \\ APEC Policy Support Unit \\ Hao Jing \\ APEC Policy Support Unit
}

Australia Indonesia Partnership for Economic Governance

\begin{abstract}
This paper develops new measures of multimodal transport connectivity, and uses a gravity model to show that improving performance could lead to major trade gains for the Asia-Pacific region. By improving multimodal connectivity by $5 \%$, APEC would increase exports by around 4\%, or between $2 \%$ and $6 \%$ per member economy. In dollar terms, this equates to an impact gain of \$500bn in total, or between $\$ 850 m$ and $\$ 115$ bn per member economy. Economies that are open, highly integrated into world markets, and with strong connectivity baselines stand to gain the most. We also find that of the elements of multimodal transport connectivity, it is logistics services performance that generally has the strongest

\footnotetext{
*Corresponding address: Ben Shepherd; Principal, Developing Trade Consultants Ltd, E-mail: Ben@ Developing-Trade.Com, Tel: +1-646-845-9702, Fax: +1-646-350-0583 / Ramonette B. Serafica; Ministry of Trade, Jl. M. I. Ridwan Rais No. 5 Blok I, 10/F Jakarta Pusat 10110, Indonesia, E-mail: ramonette.serafica@aipeg.or.id, Tel: +62 21384 2530, Fax: +62 213858180 / Akhmad Bayhaqi and Hao Jing; APEC Secretariat 35 Heng Mui Keng Terrace, Singapore 119616, Tel: +65 6891 9402, Fax: $+6568919419$

@2011-Center for Economic Integration, Sejong Institution, Sejong University, All Rights Reserved.
} 
effect on trade.

- JEL Classification: F13, F15

- Keywords: International trade, Transport, Logistics, Asia-Pacific

\section{Introduction}

The Asia-Pacific Economic Cooperation (APEC) has a long history of involvement with trade facilitation. Its two Trade Facilitation Action Plans adopted the goal of reducing trade transactions costs by five percent over five years. Although performance against this metric has been mixed, there is evidence that significant trade cost reductions have indeed taken place within the region over recent years (e.g., Shepherd 2010).

More recently, APEC has identified underdeveloped multimodal transport capabilities as one of the priority chokepoints to be addressed under the Supply Chain Connectivity Framework. ${ }^{1}$ Multimodal transport connectivity is a complex concept. It involves the quality and quantity of infrastructure, as well as the private sector's ability to coordinate intermodal linkages. It includes individual modes of transport (air, sea, and land) as well as intermodal linkages. As such, it entails a network of links (such as the roadways, railways and transport routes) and nodes (facilities such as marine ports and airports). According to Battaglia (2007), a holistic view of transportation in which individual transportation modes work together or within their own niches is a useful way to understand the concept of intermodalism.

This paper is the first attempt to comprehensively assess and model the impact of multimodal transport connectivity within APEC. Work already exists on individual modes of transport, such as air (Geloso Grosso and Shepherd 2009). Previous work on trade facilitation in APEC includes indicators of the quality of air and maritime infrastructure (Wilson et al. 2004). In addition, Limao and Venables (2001) show more generally that infrastructure - an average of performance in road, rail, and telecommunications - is an important determinant of bilateral trade. This paper extends this line of research by including air, land, and maritime links in a single modeling framework, and by showing the importance not just of modal performance, but of ensuring that all modes can work together within a

\footnotetext{
${ }^{1}$ A conclusion from the APEC Supply Chain Connectivity Symposium held in May 2009.
} 
sophisticated logistics framework.

The paper proceeds as follows. In Section II, we review the literature on the importance of multimodal transport connectivity from an economic and trade standpoint. Section III introduces the data we use to measure multimodal transport performance. In Section IV, we report results from a gravity model of bilateral trade - aggregate and by sector — augmented to include measures of multimodal transport performance. We also report the results of counterfactual simulations. Finally, Section $\mathrm{V}$ concludes and discusses the policy implications of our findings.

\section{The Importance of Multimodal Transport Connectivity}

Improvements in multimodal connectivity are immediately enjoyed by the direct users. The potential benefits to shippers are explained by Jacoby and Hodge (2008). For example, when new transportation infrastructure is built, companies take advantage by adjusting their logistics processes and supply chains. They change purchasing and operations behavior in the short-run, while in the longer term they make input substitutions and reconfigure production processes to take advantage of transportation system improvements, thereby improving service and reducing costs. The potential to reduce a company's operating costs arises from lower sourcing costs; reduced fleet, warehousing and inventory costs; and from improved transit time visibility.

The economy-wide impact captures the spillover or other related multiplier effects from the transportation and supply chain benefits. Expansion of a transportation network, as a result of multimodal connectivity brings better linkages to supplies, inputs, and final goods, thereby improving the efficiency of global supply chains in production. Improved logistics and supply chains could open up access to previously unreachable areas as well as link key economic centers in a region to national markets. The economy-wide benefits could include the following:

Trade expansion and larger foreign direct investment: Transportation and logistics improvements are critical to trade flows and the competitiveness of an economy's exports and imports. Each day saved is equivalent to an average ad valorem tariff reduction of between approximately 0.4 and $1 \%$ for export and 0.8 and $1.5 \%$ for import (Hummels et al., 2007). ${ }^{2}$ In addition, an increase in competitiveness could

\footnotetext{
${ }^{2}$ The per-day value of time savings for export and imports will be different depending on the product composition (of the related exports and imports).
} 
attract additional FDI. For manufacturers, more efficient transport links mean factories can take advantage of cheaper land and labor in the country's interior. International companies are also discovering that there are clusters of complementary businesses emerging inland that they can tap into.

Industrial impact: More trade and investment could foster growth in other industrial sectors such as tourism, manufacturing, and retail. Carruthers et al. (2003) note that improved logistics can foster faster progress in industrialization because as countries move from resource extraction to sophisticated manufacturing, they must also develop their logistics capabilities accordingly. Improved logistics will also enable more efficient (global and regional) production networks. In turn, this will result in more employment in positively affected industries/sectors through forward and backward linkages.

Regional Integration: Better transport and logistics support stronger regional integration. World Bank (2009) argues that falling transport costs have coincided with greater economic concentration within countries and have caused trade with neighbors to become even more important. Guerrero et al. (2009) argue that one explanation for why Latin American and the Caribbean (LAC) countries have lagged in their integration into the world trading system is their inability to cope with a globalization process that is inherently transport intensive and where supply chains are now being organized on a global scale.

Development and poverty reduction: Basic foodstuffs, as well as agricultural inputs like fertilizers, and development products like medicines, all need to be moved quickly and cost-effectively in order to promote human development aims. Better transportation logistics enables faster deliveries of goods and services as well as a reduction in consumer prices. Transport infrastructure also provides rural areas with access to greater participation in development opportunities that leads to a more balanced spatial development. Adequate logistics access will promote rural entrepreneurship and trade (UNESCAP 2008).

The economy-wide impact of improved multimodal connectivity will mostly be realized in the medium to long-run. Moreover, the distribution of these benefits will depend on the linkages and the integration level between the overall international supply chain and transport logistics network. For the case of an infrastructure project, size is not directly related to the economic impact that the project will have (e.g., Vickerman, 2007).

As discussed by Prentice (2003), ideally each mode of transport is used for the length of the haul that minimizes the line haul cost for the maximum distance 
moved, such that the best attributes of each mode are combined yielding the lowest cost of transportation for the supply chain. Although efficiency is a prime consideration, accessibility is a further reason for using two or more modes of transport. Moreover, intermodal transportation systems compete in terms of cost and time. For shippers of value-added goods, for example, reliability and transit time are as important as freight rates in modal choice decisions. Reliability and transit time can be affected by the level of connectivity. For maximum connectivity of intermodal transport, the absence of bottlenecks is required: a supply chain is only as strong as its weakest link.

Prentice (2003) classifies the causes of bottlenecks into three general categories, namely: infrastructure bottlenecks, regulatory bottlenecks, and supply chain dysfunctions. Chronic infrastructure bottlenecks can be due to climate and physical barriers or due to underinvestment. There are also temporary infrastructure bottlenecks which could arise from weather disruptions, market perturbations (e.g., a temporary surge in demand), and disinvestments (i.e., when parts of infrastructure are abandoned or maintained at a lower level of efficiency). Regulatory bottlenecks are described as unintended consequences of some other policy objective and these could be direct effects (e.g., safety/quality inspections and security measures) and indirect effects (e.g., cabotage restrictions). Finally, another source of bottlenecks could be due to dysfunctional supply chains which occur when participants fail to act in the common interest, for example with respect to hours of operation. Congestion and queues are symptoms of bottlenecks and careful analysis is needed in removing the bottleneck.

Although specific bottlenecks and priorities for action vary among APEC economies, there seem to be some common issues that affect the achievement of multimodal connectivity. For one, the problem of underinvestment in infrastructure is not confined to developing APEC members, and is an issue even in industrialized economies. However, it is recognized that while under-investing leads to congestion, over-investing will lead to wastage. As such, efficient use and maintenance of existing assets require attention too. Related to infrastructure provision is the need for a strategic approach to infrastructure development. Again, in both developed and developing economies, the business sector in particular stresses that transport infrastructure planning should be more closely linked with trade and other policies (e.g. land use, tax, foreign investment, etc.). More specifically, a supply chain approach to infrastructure development is seen by industry as a missing element. Failure to have an economy-wide approach and 
consideration for whole-of-supply chain requirements lead to either underprovision or under-utilization of transport infrastructure. Thus, while inadequacy of infrastructure investment is a constraint, inefficiency of investment is as crucial.

Another difficulty revolves around the sharing of costs and benefits among stakeholders or affected parties. Even when there is agreement on the overall benefits of fixing a particular bottleneck, the lack of understanding and of a mechanism to share both the risks and rewards work against achieving multimodal connectivity. The result is that critical projects do not get implemented or facilitation arrangements are slow to get off the ground.

Regulatory frameworks governing the various transport sectors could hinder the achievement of multimodal connectivity as well. Access regulations and price signals which distort modal choices and utilization are seen as key impediments to the development of optimal multimodal transport networks. One area, for example, is the need to ensure a level playing field between modes (e.g., between road and rail).

Last but not the least, the quality of service is a subject that has been highlighted. Behind this are concerns about inefficient service providers as well the shortage of required skills (both existing and forecasted), which could hamper the development and growth of the various transport and logistics industries.

Against this background, the remainder of the paper examines the performance of APEC economies when it comes to multimodal transport connectivity, and assesses the trade gains that could result from improving the situation.

\section{Measuring Multimodal Transport Connectivity}

The first stage in analyzing the relationship between APEC member economies' trade and their multimodal transport capabilities is to develop summary performance measures. Constructing multimodal transport indicators is a challenging task. Ideally, these sorts of indicators should combine data on the quantity and quality of transport facilities in each mode. Many different datasets are available that could potentially have something to add in assessing multimodal connectivity. However, there is a tradeoff between constructing broad-based indicators, and ensuring that their coverage is wide enough to take account of the heterogeneity of APEC member economies. In the interests of ensuring maximum coverage, we have chosen to base our indicators on just a small number of data series in each case.

For maritime transport, UNCTAD's Liner Shipping Connectivity Index serves as 
a readily available reference. It uses principal components analysis to combine a variety of liner shipping indicators into a single, broad-based index (UNCTAD 2009). This method produces a weighted average of the underlying data in which the weights are chosen objectively so as to produce an optimal summary measure, i.e., one that accounts for the maximum possible amount of variance in the underlying data. In this way, the LSCI takes account of the following five factors: number of ships; their container-carrying capacity; maximum vessel size; number of services; and number of companies deploying containerships to and from an economy's ports. Factors one, four, and five can be interpreted as quantity measures: they show the number of ships, services, and companies linking an economy with the rest of the world. Factors two and three are closer to being quality indicators, since they provide detail on the type of service provided, rather than just the quantity.

The LSCI has previously been used in policy analysis. Wilmsmeier and Hoffmann (2008) show that connectivity has an important impact on maritime freight rates. However, the present paper is, to our knowledge, the first one to use the LSCI in an econometric analysis of the determinants of trade flows in goods markets.

No similar indicator to the LSCI exists for air transport. ${ }^{3}$ To construct a comparable indicator for that sector, we use principal components to obtain a weighted average of two underlying data series: the number of primary airports in each member economy; and the number of secondary airports. Both variables are sourced from the CIA World Factbook. We use these variables rather than alternative sources such as the World Development Indicators or the Global Competitiveness Report, since they provide the best coverage of APEC member economies. The total number of airports is a quantity measure of connectivity, whereas the division between primary and secondary airports gives an idea of the quality of the air transport sector.

Land transport is also an important aspect of multimodal transport connectivity. It is primarily associated with the transport of goods within, rather than between,

\footnotetext{
${ }^{3}$ The WTO's Air Liberalization Index is in a different category: it measures an input (degree of policy liberalization), as compared with output measures such as the LSCI. We exclude it from the empirical modeling for that reason, and because lack of data availability for many bilateral links makes it difficult to obtain reliable estimates of the impact of liberalization. For detailed results on intra-APEC trade, see Geloso-Grosso and Shepherd (2009). Those authors find that sectors such as parts and components are particularly sensitive to air transport liberalization. A one point increase in a bilateral air services agreement's ALI score is associated with an up to $4 \%$ increase in merchandise trade. For an alternative approach to measuring liberalization, see: APEC TPT-WG (2007).
} 
countries. But international trade transactions are often impossible to complete without a strong land transport environment to facilitate shipping between factory, port, and warehouse. We again use principal components to produce an overall land transport indicator, based on a weighted average of the following indicators: road infrastructure density; and rail infrastructure density. Each measure is defined as the total length of the network divided by the economy's total land area; this is a similar approach to Limao and Venables (2001). Both data series are sourced from the CIA World Factbook. As for air transport, the composite index captures the twin aspects of the quantity (length of the network) and quality (adjustment for land area) of connections.

The final major dimension of multimodal transport connectivity is the logistics environment. Logistics operators are responsible for coordinating complex crossborder transactions involving a variety of transport modes, as well as the necessary interchanges and transshipments. The most comprehensive dataset on an economy's "logistics friendliness" is the World Bank's Logistics Performance Index (LPI). The LPI is based on private sector perceptions of supply-chain performance and bottlenecks, drawn from survey responses given by logistics professionals around the world. Like the LSCI and our transport indicators, it uses principal components analysis to create a single, comprehensive index based on the following core dimensions: efficiency of the clearance process; quality of trade and transport infrastructure; ease of arranging competitively priced shipments; competence and quality of logistics services; ability to track and trace consignments; and timeliness of delivery. We use one of those dimensions to measure an economy's ability to coordinate complex multimodal transactions, namely the competence and quality of logistics services. Although the overall LPI has been used in econometric work on the determinants of goods trade (Hoekman and Nicita 2008), the logistics competence component has not yet, to our knowledge, received such detailed attention.

To obtain an overall picture of multimodal transport connectivity across the region, we use principal components analysis to create a summary indicator (Figure 1). This indicator incorporates the air, maritime, and land transport indicators, as well as logistics competence from the LPI. Data are available for 19 APEC member economies. There is a strong correlation between our overall indicator and each of the modal indicators.. The overall indicator clearly captures an important tendency of the full range of modal data, and should be a useful indicator of multimodal transport connectivity. 
Figure 1. Multimodal transport indicator, as a percentage of the regional leader's score

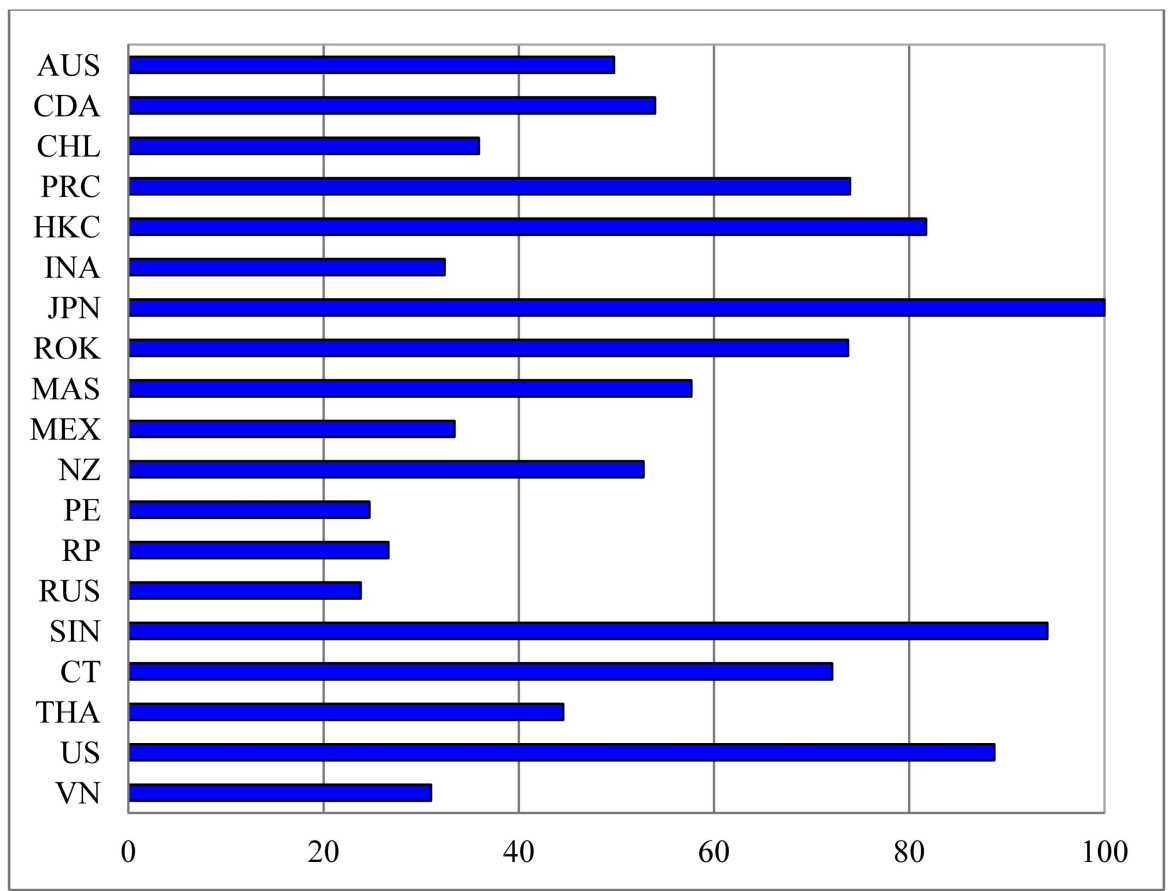

Detailed results from the principal components analyses for air transport, land transport, and overall multimodal performance are set out in Table 1. The table presents loading factors for each component, i.e., the weight accorded to each indicator in constructing the summary measure.

Table 1. Results of principal components analysis

\begin{tabular}{|c|c|c|c|c|c|}
\hline $\begin{array}{l}\text { Air Transport } \\
\text { Variable }\end{array}$ & Loading & $\begin{array}{l}\text { Land Transport } \\
\text { Variable }\end{array}$ & Loading & $\begin{array}{l}\text { Multimodal } \\
\text { Transport Variable }\end{array}$ & Loading \\
\hline $\begin{array}{l}\text { Number of } \\
\text { primary airports }\end{array}$ & 0.7071 & $\begin{array}{l}\text { Road network } \\
\text { density }\end{array}$ & 0.7071 & Air Transport & 0.2048 \\
\hline \multirow[t]{3}{*}{$\begin{array}{l}\text { Number of } \\
\text { secondary airports }\end{array}$} & 0.7071 & $\begin{array}{l}\text { Rail network } \\
\text { density }\end{array}$ & 0.7071 & Land Transport & 0.5336 \\
\hline & & & & Logistics & 0.6081 \\
\hline & & & & Maritime Transport & 0.5510 \\
\hline
\end{tabular}

Note: Eigenvalues for the first principal components are 1.9, 1.4, and 2.03 respectively. 


\section{Multimodal Transport and Exports: Empirical Analysis using the Gravity Model}

Figure 2 provides a preliminary analysis of the relationship between multimodal transport performance and trade in APEC. The horizontal axis shows each economy's score on our overall multimodal transport connectivity indicator. The vertical axis shows the same economy's total exports (converted to logarithms to improve readability). The line of best fit is strongly upward sloping: better multimodal transport connectivity is clearly associated with better export performance.

Another striking feature of the graph is that some member economies perform far better than the average relation between multimodal transport and exports would seem to suggest, as indicated by data points well above the line of best fit. In some cases, such as Russia, this result must be interpreted with caution because oil exports play a role in boosting export values, but they are not overly dependent on transport and logistics performance. Given its export mix, the case of China is more noteworthy. It may be that one of the reasons for its strong performance compared with the average is that in such a large and diverse economy, our general measures of transport connectivity do not capture the fact that major international

Figure 2. Correlation between exports and multimodal transport performance in APEC

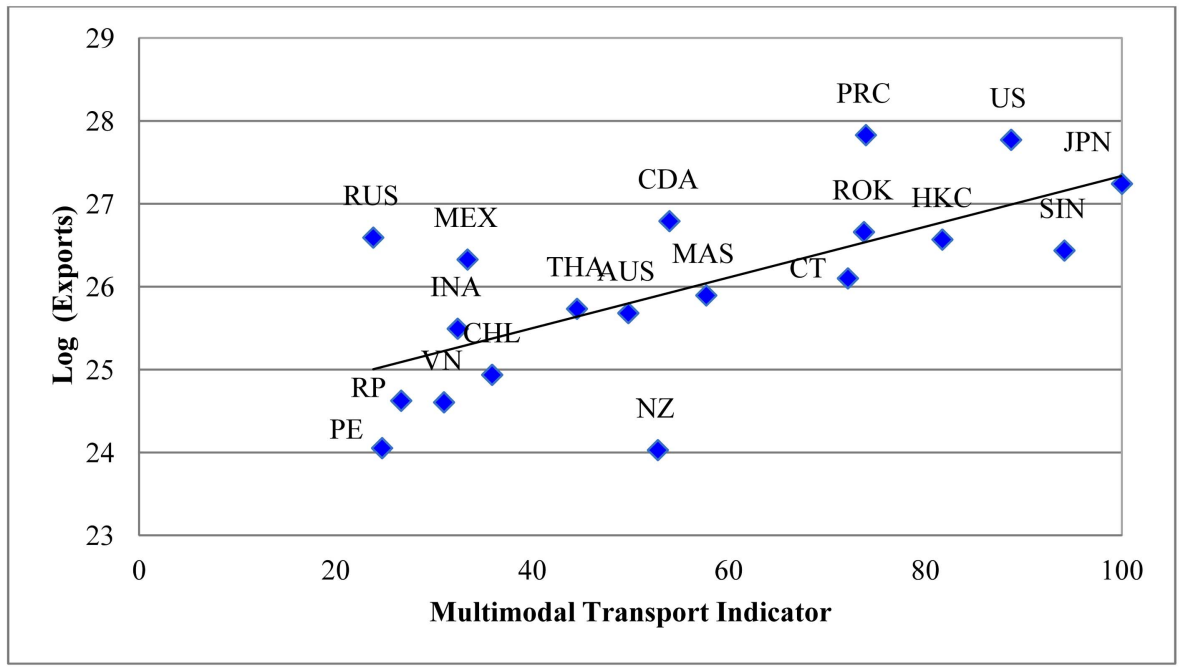


gateways may be of much better than average quality compared with infrastructure in the hinterland.

We use the gravity model of bilateral trade to investigate the association between multimodal transport connectivity and trade in greater depth. It takes account of trade within APEC, and between APEC member economies and the rest of the world (up to 230 economies in total). The model controls for a range of influences on bilateral trade, such as the size of each economy, and the level of trade costs between them.

\section{A. Specification of the gravity model}

The starting point for the analysis is a gravity model based on standard theories of international trade (Anderson \& Van Wincoop 2003, 2004). It takes the following form:

$$
\begin{aligned}
\log \left(X_{i j}^{k}\right)= & \log \left(E_{j}^{k}\right)+\log \left(Y_{i}^{k}\right)-\log \left(Y^{k}\right)+\left(1-s^{k}\right) \log \left(t_{i j}^{k}\right)-(1-\sigma) \log \left(P_{j}^{k}\right) \\
& -\left(1-s^{k}\right) \log \left(\Pi_{i}^{k}\right)+e_{i j}^{k}
\end{aligned}
$$

where: $X_{i j}^{k}$ is exports from economy $i$ to economy $j$ in sector $k$; $E_{j}^{k}$ is sectoral expenditure in economy $j$; $Y_{i}^{k}$ is sectoral production in economy $i ; t_{i j}^{k}$ is bilateral trade costs; $s^{k}$ is the intra-sectoral elasticity of substitution (between varieties within a sector); and $e_{i j}^{k}$ is a random error term satisfying standard assumptions. The $P_{j}^{k}$ and $\Pi_{i}^{k}$ terms represent multilateral resistance, i.e. the fact that trade patterns are determined by the level of bilateral trade costs relative to trade costs elsewhere in the world. Inward multilateral resistance $\left(P_{j}^{k}\right)^{(1-s)}=\Sigma_{i=1}^{N}\left(\Pi_{i}^{k}\right)^{(s-1)} w_{i}\left(t_{i j}^{k}\right)^{(1-s)}$ captures the dependence of economy $j$ 's imports on trade costs across all suppliers. Outward multilateral resistance $\left(\Pi_{i}^{k}\right)^{(1-s)}=\Sigma_{i=1}^{N}\left(P_{j}^{k}\right)^{(s-1)} w_{j}\left(t_{i j}^{k}\right)^{(1-s)}$ captures the dependence of economy $i$ 's exports on trade costs across all destination markets. The $w$ terms are weights equivalent to each economy's share in global output or expenditure.

Ideally, empirical work based on equation (1) should fully account for multilateral resistance, for example by using fixed effects. This is not possible in the present case, however, since the analysis is focused on data that vary by exporting economy but not across importers for a given exporter. Indicators of multimodal transport performance would be perfectly collinear with exporter fixed effects, and the model therefore could not be estimated.

A second-best estimation option is to use fixed effects to account for inward 
multilateral resistance, and random effects for outward multilateral resistance (equation 2). The random effects specification puts more structure on the data than fixed effects, since it assumes that outward multilateral resistance can be adequately summarized by a random variable that follows a normal distribution; a fixed effects specification allows for unconstrained variation. The mixed effects model with fixed effects by importer and random effects by exporter represents an acceptable compromise in this case between research objectives and empirical rigor.

$$
\begin{gathered}
\log \left(X_{i j}^{k}\right)=\mathrm{r}_{\mathrm{i}}^{\mathrm{k}}+\log \left(Y_{i}^{k}\right)+\mathrm{f}_{\mathrm{j}}^{\mathrm{k}}-\log \left(Y^{k}\right)+\left(1-s^{k}\right) \log \left(t_{i j}^{k}\right)+e_{i j}^{k} \\
r_{i}^{k} \sim N\left(0, v_{i}^{k}\right)
\end{gathered}
$$

The final part of the model is the trade costs function $t$. The basic specification (equation 3) includes the indicators of maritime, air, and logistics performance discussed above. It also includes standard gravity model control variables such as distance (a proxy for transport costs), tariffs, colonial connections, common language, and APEC membership of the exporting and importing economies jointly.

$$
\begin{aligned}
\log \left(t_{i j}^{k}\right)= & b_{1} \log \left(\text { sea }_{i}\right)+b_{2} \log \left(\text { air }_{i}\right)+b_{3} \log \left(\text { land }_{i}\right)+b_{4} \log \left(\text { logistics }_{i}\right) \\
& +b_{5} \log \left(\text { distance }_{i j}\right)+b_{6} \text { tariff }_{i j}^{k}+b_{7} \text { APEC }_{i j}+b_{8} \text { border }_{i j} \\
& +b_{9} \text { language }_{i j}+b_{10} \text { colony }_{i j}+b_{11} \text { clonizer }_{i j}
\end{aligned}
$$

To estimate the model, we substitute equation (3) into equation (2) and proceed using the standard GLS estimator. ${ }^{4}$ The presence of zeros in the bilateral trade matrix - 132 out of 3790 observations for total trade - means that we need to adjust the export data by adding one prior to taking the logarithm.

\section{B. Data sources}

For the most part, the gravity modeling work presented here uses standard data sources, in addition to the multimodal transport data discussed above. Table 2 provides a full summary. Export data are taken from UN Comtrade accessed via the World Bank's WITS platform, and cover total exports and exports by one digit

\footnotetext{
${ }^{4}$ Results using our multimodal transport indicator are completely robust to the use of Poisson as an alternative estimator (Santos Silva and Tenreyro 2006), as well as estimation using the Baier and Bergstrand (2009) approximation to control for multilateral resistance. Results are available on request.
} 
Table 2. Data and sources

\begin{tabular}{|c|c|c|c|}
\hline Variable & Description & Year & Source \\
\hline Air Transport & $\begin{array}{l}\text { First principal component of the following indica- } \\
\text { tors: the number of primary and secondary airports. }\end{array}$ & 2007 & $\begin{array}{l}\text { CIA World } \\
\text { Factbook. }\end{array}$ \\
\hline APEC & $\begin{array}{l}\text { Dummy variable equal to unity if both economies } \\
\text { are APEC member economies. }\end{array}$ & $\mathrm{n} / \mathrm{a}$ & $\mathrm{n} / \mathrm{a}$ \\
\hline Colony & $\begin{array}{l}\text { Dummy variable equal to unity if one economy was } \\
\text { once a colony of the other. }\end{array}$ & $\mathrm{n} / \mathrm{a}$ & CEPII. \\
\hline $\begin{array}{l}\text { Common } \\
\text { Border }\end{array}$ & $\begin{array}{l}\text { Dummy variable equal to unity for economies that } \\
\text { share a common land border. }\end{array}$ & $\mathrm{n} / \mathrm{a}$ & CEPII. \\
\hline $\begin{array}{l}\text { Common } \\
\text { Colonizer }\end{array}$ & $\begin{array}{l}\text { Dummy variable equal to unity for economies that } \\
\text { were colonized by the same power. }\end{array}$ & $\mathrm{n} / \mathrm{a}$ & CEPII. \\
\hline $\begin{array}{l}\text { Common } \\
\text { Language }\end{array}$ & $\begin{array}{l}\text { Dummy variable equal to unity for economies that } \\
\text { share a language spoken by more than } 9 \% \text { of the } \\
\text { population. }\end{array}$ & $\mathrm{n} / \mathrm{a}$ & CEPII. \\
\hline Distance & $\begin{array}{l}\text { Great circle distance between the main cities of } \\
\text { economies } i \text { and } j \text {, weighted by internal distance }\end{array}$ & $\mathrm{n} / \mathrm{a}$ & CEPII. \\
\hline Exports & $\begin{array}{l}\text { Total and BEC 1-digit exports from economy } i \text { to } \\
\text { economy } j \text {. }\end{array}$ & 2007 & $\begin{array}{l}\text { Comtrade via } \\
\text { WITS; } \\
\text { SourceOECD. }\end{array}$ \\
\hline GDP & Nominal GDP in USD. & 2007 & $\begin{array}{l}\text { World Devel- } \\
\text { opment Indica- } \\
\text { tors. }\end{array}$ \\
\hline Land Transport & $\begin{array}{l}\text { First principal component of the following indica- } \\
\text { tors: road network length / land area; and rail net- } \\
\text { work length / land area. }\end{array}$ & 2007 & $\begin{array}{l}\text { CIA World } \\
\text { Factbook; and } \\
\text { World Devel- } \\
\text { opment Indica- } \\
\text { tors. }\end{array}$ \\
\hline Logistics & $\begin{array}{l}\text { Logistics Performance Index score on the compe- } \\
\text { tence and quality of logistics services. }\end{array}$ & 2007 & World Bank. \\
\hline $\begin{array}{l}\text { Maritime } \\
\text { Transport }\end{array}$ & Liner Shipping Connectivity Index score. & 2007 & UNCTAD. \\
\hline $\begin{array}{l}\text { Multimodal } \\
\text { Transport }\end{array}$ & $\begin{array}{l}\text { First principal component of: Air Transport; Land } \\
\text { Transport; Logistics; and Maritime Transport. }\end{array}$ & 2007 & $\begin{array}{l}\text { Own calcula- } \\
\text { tions }\end{array}$ \\
\hline $\begin{array}{l}\text { Population } \\
\text { Density }\end{array}$ & Population density (population per square km.). & 2007 & $\begin{array}{l}\text { World Devel- } \\
\text { opment Indica- } \\
\text { tors }\end{array}$ \\
\hline Tariff Rate & Effectively applied tariff, trade weighted average. & 2007 & $\begin{array}{l}\text { TRAINS via } \\
\text { WITS. }\end{array}$ \\
\hline
\end{tabular}

sector following the Broad Economic Classification system. For Chinese Taipei, export data come from Source OECD. For convenience, BEC sectors one and three (food and fuels) are aggregated into a single sector, as are sectors four and five (capital goods and transport equipment), and sectors six and seven (consumer and 
other goods).

Tariff data are from UNCTAD's TRAINS database, accessed via WITS. Tariff rates are effective bilateral rates that take account of regional and preferential trade agreements. They are averaged by applying trade weights.

The model also includes standard gravity model controls such as the distance between economies, colonial history, and common language. All such variables come from CEPII's distance database (http://www.cepii.fr/anglaisgraph/bdd/ distances.htm).

\section{Empirical results using aggregate trade}

We start by estimating the gravity model using data on total exports from APEC members to up to 229 overseas markets. Results are in Table 3. The first two columns provide baseline results for comparative purposes, and exclude data on multimodal transport performance. Column 1 estimates the gravity model using fixed effects by exporter and by importer, in a way that is fully consistent with theory (Anderson \& Van Wincoop 2003, 2004). Column 2 re-estimates the same model using fixed effects by importer and random effects by exporter, as discussed above.

Both models give results that accord with the general gravity model literature. The coefficients on GDP, APEC, common language, and colonial history, are all positive and statistically significant. The common border dummy has a statistically significant coefficient in column 2 only. The coefficients on distance and tariffs are negatively signed, and both statistically significant in column 1 . In column 2 , only distance has a statistically significant coefficient.

Although there are some differences in estimated coefficients between the models in columns 1-2, they are generally quite minor. The similarity in the two sets of estimates confirms that it is appropriate to continue with the mixed effects model as an approximation to the true, theoretically-grounded model. The largest difference between the two sets of estimates is in relation to the APEC coefficient, which is positive and statistically significant in both specifications, but has a much larger coefficient in the mixed effects regression. One possible reason for the difference is close correlation between the APEC variable and the fixed effects, since it is the multiple of each economy's APEC membership.

Columns 3-8 present results using the augmented gravity model. Each column introduces a different variable or set of variables measuring multimodal transport. Column 3 includes maritime transport only, and the estimated coefficient is 
positive and statistically significant, which indicates that improved maritime links have the potential to boost APEC member economies' trade. Columns 5 and 6 find similar results for land transport, and logistics competence: both estimated coefficients are positive and statistically significant. In column 4 , however, the coefficient on air transport is positive, as expected, but it is not statistically significant.

Results in columns 3-6 should be interpreted cautiously due to omitted variable bias: in each case, only one multimodal transport indicator is included in the regression. In column 7, the model is augmented to include all four multimodal transport indicators simultaneously, and thus avoid the bias problem in the previous results. Results in this case are similar to columns 3-6 for maritime transport, land transport, and logistics performance: they all have coefficients that are positive and at least 5\% significant. In addition, the coefficient on air transport is now positive and statistically significant (1\%), which is in line with expectations. This result highlights the importance of including all variables together for all but preliminary, exploratory regressions.

The regression results in column 7 allow us to say something about the relative sensitivity of APEC trade flows to the various dimensions of multimodal transport performance. The variable with the strongest impact is logistics competence: a one point increase in our index, where 100 represents the regional leader, is associated with an impact effect on trade of $2.3 \%$. The variable with the next strongest impact is maritime transport, however it is around half as strong as that of logistics competence. A one point increase in the maritime transport index is associated with a trade increase of just over $1 \%$. Next in line comes air transport, with an effect just slightly weaker than that of maritime transport. Land transport has the weakest effect, with a one point increase in the index being associated with a $0.5 \%$ increase in trade.

Next, we run an additional regression using the index of multimodal transport discussed above, i.e., a principal component weighted average of the other four indices (maritime transport, land transport, air transport, and logistics competence). The reason for aggregating the indices in this way for regression purposes is twofold. First, it takes account of the strong correlations among them, which can lead to inflated standard errors. Second, it provides a more robust basis for counterfactual simulations (see below), since it eliminates multiple counting of performance improvements that might otherwise take place due to the strong correlations among indicators. 
Results in column 8 are fully in line with expectations. The multimodal transport indicator has a positive and $1 \%$ significant coefficient. Its magnitude is greater than those of any of the individual transport modes in column 7. Concretely, an improvement in overall multimodal transport performance that brings an economy one point closer to the regional leader is associated with an export increase of around 3\%. This result again suggests that overall performance is strongly influenced not just by performance in each mode, but also by the ability to make each mode work efficiently and effectively with the others.

Reverse causality is clearly an issue in this model due to the possibility of a virtuous cycle between trade and multimodal transport performance. Column 9 confronts this problem using the statistical methodology of instrumental variables, or two-stage generalized least squares (2SGLS). The 2SGLS estimator uses an external variable - the instrument - to purge multimodal transport performance of the causal influence that trade flows might exert on it. The instrument must be strongly correlated with multimodal transport, but must not affect trade through any other variable in the model. In this case, we use population density as an instrument. We expect economies with higher population densities to have better multimodal transport performance because geographical agglomeration makes it easier for different modes to work together, and also makes infrastructure development less expensive due to the need to cover less territory. The data strongly support this contention: the first stage coefficient on population density is $6.744^{* * *}(\mathrm{z}=53.19)$. Since there is no other way that population density can affect international trade flows, we expect it to satisfy both criteria for instrument validity.

Column 9 presents results from the second stage of the 2SGLS regression. The coefficient on multimodal transport is smaller in magnitude, but it remains $1 \%$ statistically significant. A fall in the value of the coefficient is exactly what we would expect from a "virtuous cycle" causal dynamic involving trade and multimodal transport performance. Based on the 2SGLS results-which are the most robust ones available - a one point increase in the multimodal transport index is associated with a trade increase of around $1 \%$.

\section{Counterfactual simulations}

To express the regression results in a different way, we also conduct counterfactual simulations. We look at the trade impacts of improving multimodal transport performance in all APEC member economies. We assume that each economy implements reforms that improve multimodal transport performance by 
Table 3. Gravity model regression results using data on total exports

\begin{tabular}{|c|c|c|c|c|c|c|c|c|c|}
\hline & (1) & (2) & (3) & (4) & (5) & (6) & (7) & (8) & (9) \\
\hline Maritime Transport & & & $\begin{array}{c}0.023^{* * *} \\
(0.000)\end{array}$ & & & & $\begin{array}{c}0.012 * * * \\
(0.000)\end{array}$ & & \\
\hline Air Transport & & & & $\begin{array}{l}-0.003 \\
(0.280)\end{array}$ & & & $\begin{array}{c}0.009 * * * \\
(0.002)\end{array}$ & & \\
\hline Land Transport & & & & & $\begin{array}{c}0.019 * * * \\
(0.000)\end{array}$ & & $\begin{array}{c}0.005^{* *} \\
(0.019)\end{array}$ & & \\
\hline Logistics Competence & & & & & & $\begin{array}{c}0.030 * * * \\
(0.000)\end{array}$ & $\begin{array}{c}0.023 * * * \\
(0.000)\end{array}$ & & \\
\hline Multimodal Transport & & & & & & & & $\begin{array}{c}0.032 * * * \\
(0.000)\end{array}$ & $\begin{array}{c}0.010 * * * \\
(0.009)\end{array}$ \\
\hline $\log (\mathrm{GDP})$ & & $\begin{array}{c}0.947 * * * \\
(0.000)\end{array}$ & $\begin{array}{c}0.778 * * * \\
(0.000)\end{array}$ & $\begin{array}{c}0.976 * * * \\
(0.000)\end{array}$ & $\begin{array}{c}0.853 * * * \\
(0.000)\end{array}$ & $\begin{array}{c}0.806 * * * \\
(0.000)\end{array}$ & $\begin{array}{c}0.641 * * * \\
(0.000)\end{array}$ & $\begin{array}{c}0.657^{* * * *} \\
(0.000)\end{array}$ & $\begin{array}{c}0.861 * * * \\
(0.000)\end{array}$ \\
\hline Log(Distance) & $\begin{array}{c}-1.703 * * * \\
(0.000)\end{array}$ & $\begin{array}{c}-1.560 * * * \\
(0.000)\end{array}$ & $\begin{array}{c}-1.558 * * * \\
(0.000)\end{array}$ & $\begin{array}{c}-1.563 * * * \\
(0.000)\end{array}$ & $\begin{array}{c}-1.578 * * * \\
(0.000)\end{array}$ & $\begin{array}{c}-1.809 * * * \\
(0.000)\end{array}$ & $\begin{array}{c}-1.747 * * * \\
(0.000)\end{array}$ & $\begin{array}{c}-1.688^{* * *} \\
(0.000)\end{array}$ & $\begin{array}{c}-1.598^{* * *} \\
(0.000)\end{array}$ \\
\hline Tariff Rate & $\begin{array}{l}-0.016^{*} \\
(0.076)\end{array}$ & $\begin{array}{l}-0.016 \\
(0.145)\end{array}$ & $\begin{array}{l}-0.007 \\
(0.504)\end{array}$ & $\begin{array}{l}-0.016 \\
(0.145)\end{array}$ & $\begin{array}{l}-0.007 \\
(0.516)\end{array}$ & $\begin{array}{l}0.018^{*} \\
(0.061)\end{array}$ & $\begin{array}{l}0.018^{*} \\
(0.067)\end{array}$ & $\begin{array}{c}0.013 \\
(0.169)\end{array}$ & $\begin{array}{l}-0.007 \\
(0.466)\end{array}$ \\
\hline APEC & $\begin{array}{c}9.901 * * * \\
(0.001)\end{array}$ & $\begin{array}{c}3.734 * * * \\
(0.000)\end{array}$ & $\begin{array}{c}3.785 * * * \\
(0.000)\end{array}$ & $\begin{array}{c}3.737 * * * \\
(0.000)\end{array}$ & $\begin{array}{c}3.606 * * * \\
(0.000)\end{array}$ & $\begin{array}{c}3.197 * * * \\
(0.000)\end{array}$ & $\begin{array}{c}3.303 * * * \\
(0.000)\end{array}$ & $\begin{array}{c}3.400 * * * \\
(0.000)\end{array}$ & $\begin{array}{c}3.635 * * * \\
(0.000)\end{array}$ \\
\hline Common Language & $\begin{array}{c}0.621 * * * \\
(0.000)\end{array}$ & $\begin{array}{c}0.395 * * \\
(0.014)\end{array}$ & $\begin{array}{c}0.435 * * * \\
(0.006)\end{array}$ & $\begin{array}{c}0.409 * * \\
(0.012)\end{array}$ & $\begin{array}{c}0.455^{* * *} \\
(0.004)\end{array}$ & $\begin{array}{l}-0.040 \\
(0.794)\end{array}$ & $\begin{array}{c}0.058 \\
(0.716)\end{array}$ & $\begin{array}{c}0.224 \\
(0.139)\end{array}$ & $\begin{array}{c}0.344 * * \\
(0.028)\end{array}$ \\
\hline Common Border & $\begin{array}{c}0.369 \\
(0.244)\end{array}$ & $\begin{array}{c}0.705 * * * \\
(0.009)\end{array}$ & $\begin{array}{l}0.632 * * \\
(0.016)\end{array}$ & $\begin{array}{c}0.704 * * * \\
(0.009)\end{array}$ & $\begin{array}{c}0.924 * * * \\
(0.001)\end{array}$ & $\begin{array}{c}1.043 * * * \\
(0.000)\end{array}$ & $\begin{array}{c}0.993 * * * \\
(0.000)\end{array}$ & $\begin{array}{c}0.993 * * * \\
(0.000)\end{array}$ & $\begin{array}{c}0.791 * * * \\
(0.005)\end{array}$ \\
\hline Common Colonizer & $\begin{array}{c}0.746^{* * *} \\
(0.000)\end{array}$ & $\begin{array}{c}0.868 * * * \\
(0.001)\end{array}$ & $\begin{array}{c}0.096 \\
(0.727)\end{array}$ & $\begin{array}{c}0.875 * * * \\
(0.001)\end{array}$ & $\begin{array}{c}0.648^{* * * *} \\
(0.009)\end{array}$ & $\begin{array}{c}0.344 \\
(0.188)\end{array}$ & $\begin{array}{l}-0.016 \\
(0.953)\end{array}$ & $\begin{array}{l}-0.004 \\
(0.988)\end{array}$ & $\begin{array}{c}0.608 * * \\
(0.021)\end{array}$ \\
\hline Colony & $\begin{array}{c}1.968 * * * \\
(0.000)\end{array}$ & $\begin{array}{c}1.308^{* * * *} \\
(0.001)\end{array}$ & $\begin{array}{c}1.628 * * * \\
(0.000)\end{array}$ & $\begin{array}{c}1.319 * * * \\
(0.001)\end{array}$ & $\begin{array}{c}1.302 * * * \\
(0.001)\end{array}$ & $\begin{array}{c}1.591^{* * * *} \\
(0.000)\end{array}$ & $\begin{array}{c}1.660 * * * \\
(0.000)\end{array}$ & $\begin{array}{c}1.604^{* * *} \\
(0.000)\end{array}$ & $\begin{array}{c}1.396^{* * *} \\
(0.000)\end{array}$ \\
\hline Obs. & 3262 & 3124 & 3124 & 3124 & 3124 & 3124 & 3124 & 3124 & 3124 \\
\hline$R^{2}$ & 0.754 & 0.638 & 0.649 & 0.638 & 0.645 & 0.656 & 0.659 & 0.657 & 0.648 \\
\hline$\chi^{2}$ or $F$ & $47.906^{* * *}$ & $8370.949 * * *$ & $7694.176^{* * *}$ & $8328.907 * * *$ & $8291.500 * * *$ & $7537.634 * * *$ & $7853.846^{* * *}$ & $7940.259 * * *$ & $16718.74 * * *$ \\
\hline $\begin{array}{l}\text { Fixed Effects } \\
\text { Random Effects }\end{array}$ & $\begin{array}{l}\text { Importer } \\
\text { Exporter }\end{array}$ & $\begin{array}{l}\text { Importer } \\
\text { Exporter }\end{array}$ & $\begin{array}{l}\text { Importer } \\
\text { Exporter }\end{array}$ & $\begin{array}{l}\text { Importer } \\
\text { Exporter }\end{array}$ & $\begin{array}{l}\text { Importer } \\
\text { Exporter }\end{array}$ & $\begin{array}{l}\text { Importer } \\
\text { Exporter }\end{array}$ & $\begin{array}{l}\text { Importer } \\
\text { Exporter }\end{array}$ & $\begin{array}{l}\text { Importer } \\
\text { Exporter }\end{array}$ & $\begin{array}{l}\text { Importer } \\
\text { Exporter }\end{array}$ \\
\hline
\end{tabular}

Note: The dependent variable is $\log (1+$ Exports) in all cases. Estimation is by OLS and GLS in columns 1-8, and 2SGLS in column 9. Standard errors are robust, and adjusted for clustering by reporter, in parentheses below the coefficient estimates. Statistical significance is indicated by: $* 10 \%, * * 5 \%$, and $* * * 1 \%$. 
$5 \%$ from its initial level in 2007. We assume that they act in a concerted way, i.e., all economies undertake similar reforms simultaneously.

Gravity model counterfactuals need to be conducted carefully to make sure that they properly account for changes in multilateral resistance. Failure to account for these effects can lead to serious upward bias in the estimates of gains from reform. We therefore adopt a different technique from previous work on trade facilitation (e.g., Wilson et al. 2005), which does not account for multilateral resistance in their counterfactual analysis. We use the estimated 2SGLS parameters from the mixed effects regression model (Table 3 column 9), but we undertake the counterfactual analysis using the approximation of the exporter's multilateral resistance term introduced by Baier and Bergstrand (2009):

$$
\log P_{i}^{(1-s)} \approx(s-1)\left[\sum w_{j} \log t_{i j}-\frac{1}{2} \sum \sum w_{i} w_{j} \log t_{i j}\right]
$$

Proceeding in this way provides more accurate simulation results for the case of concerted reform than does applying the regression coefficients directly to counterfactual values of trade facilitation variables. As Anderson and Van Wincoop (2003) and Baier and Bergstrand (2009) show, the difference can be quantitatively important. In general, results obtained using the present methodology show smaller trade gains from a given level of reform than do those obtained using the Wilson et al. (2005) approach. However, the simulation only takes account of reform and multilateral resistance on the export side. It does not consider changes in import policies or behavior. The reason for this is that the focus on this paper is on exports, and so the regression models are constructed with importer fixed effects to account for multimodal transport performance on the import side, rather than including data directly.

Results in Figure 3 show that the trade gains from improving multimodal transport performance can be substantial. The range for individual member economies is between $2 \%$ and $6 \%$ of baseline exports. In dollar terms, this equates to an impact gain of between $\$ 850 \mathrm{~m}$ and $\$ 115 \mathrm{bn}$ per member economy. On the whole, exports to the world would increase by nearly $\$ 500 \mathrm{bn}$ annually or an increase of $4 \%$. High performers in multimodal transport, like Singapore and Japan, have the most to gain: 5\% improvements in these economies represent substantial performance upgrades. Economies with challenging multimodal transport environments see smaller, but still significant, gains from reform: at a minimum, an increase in exports of nearly $2 \%$ follows concerted reforms that 
Figure 3. Simulated percentage change in exports from a 5\% improvement in multimodal transport performance, based on the gravity model (Table 3 Column 9)

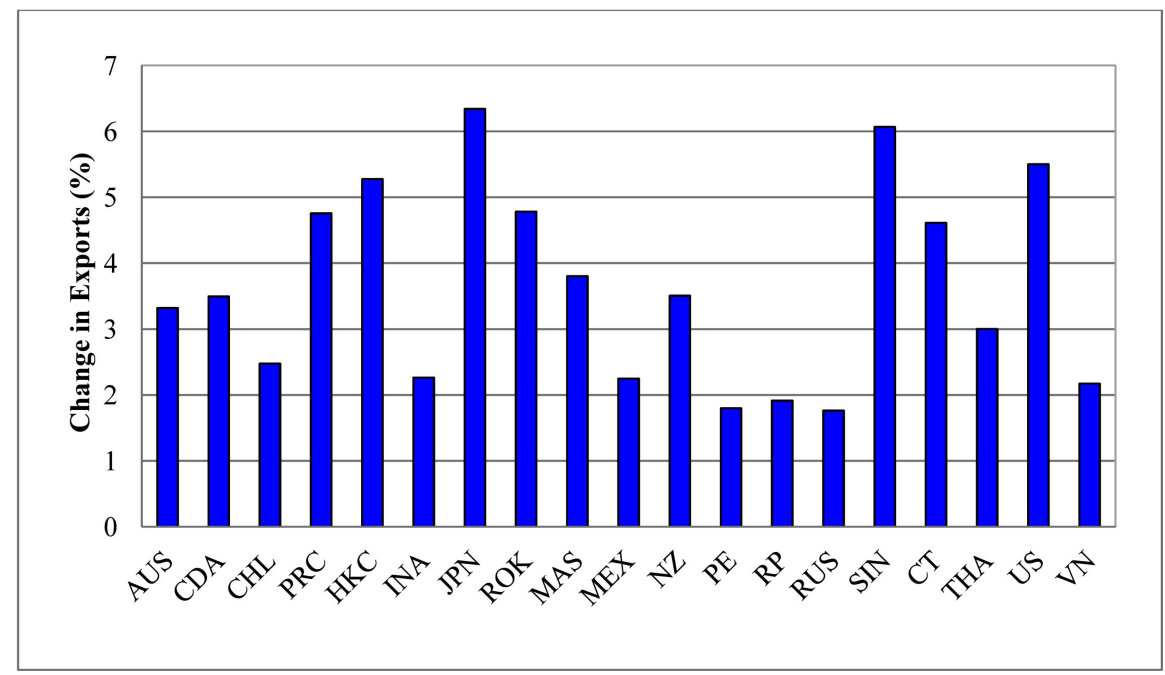

improve multimodal transport performance by $5 \%$.

Another feature of the simulation results is that relatively small and open economies stand to realize significant gains from reform. Although Chile is starting from a transport environment with a certain number of constraints - its score is less than $40 \%$ that of the regional leader-it experiences major export gains from reform because its starting level of trade exposure is relatively high; its trade to GDP ratio is just over $40 \%$.

\section{E. Empirical results by sector}

Table 4 presents results for the same gravity model as in column 8 of Table 3, but using data disaggregated by sector. Although the main thrust of our paper is on the overall links between trade and multimodal transport connectivity at the aggregate level, it is useful to provide some preliminary indications as to the way in which that link might change according to sectoral particularities. The sectoral classification we use follows the one digit level of the Broad Economic Classification system (BEC). Looking across the columns of Table 4 makes it possible multimodal transport connectivity.

Five of the seven regressions in Table 4 have a multimodal transport coefficient that is positively signed and statistically significant, which is in line with 
expectations and with the aggregate results. Only for fuels and lubricants, and food and beverages, does the coefficient have an unexpected and statistically significant sign. The reasons for these unexpected results are likely to be a combination of smaller sample size due to the use of a single sector only, and lack of homogeneity in the product classification. In addition, trade in agricultural products is subject to a range of non-tariff measures that are not easily captured in a gravity regression. Similarly, exports of fuels and lubricants are subject to the dynamics of international commodity markets in a way that is not easily captured in a gravity model framework.

The magnitude of the coefficient on multimodal transport performance varies from one regression to another. This reflects the fact that different sectors respond differently to improvements. The sensitivity of trade to multimodal transport is particularly strong in the consumer goods sector, followed by capital goods, transport equipment, other goods, and industrial supplies.

Pushing the data one step further, we can also produce results using data on individual transport modes (Table 5). The motivation is again to obtain some initial indications as to the sectors that might be most sensitive to improvements in particular types of transport performance. However, these results should be taken as indicative only, because the combination of reduced sample size and strong correlation among the transport variables leads to inflated standard errors, and estimates that are sometimes difficult to interpret.

Moving across Table 5, maritime transport plays an important role in exports of consumer goods, capital goods, and industrial supplies. Air transport is especially important for exports of food, and to a lesser extent consumer and other goods, and industrial products. Land transport appears to be particularly important for exports of transport equipment. The most consistent results from any of the four indicators come from logistics competence. It is a significant determinant of trade performance in all sectors.

A number of results in Table 5 are inconsistent with expectations, however, in that the estimated coefficients on some of the multimodal transport indicators have coefficients that are negative and, in some cases, statistically significant. Where coefficients are not significant, the effect of the transport mode in question can be considered to be negligible for the sector in that regression. Where coefficients are significant, there are two possible explanations for the model's poor performance. First, samples are in some cases very small —as low as 679 observations, compared with over 3,000 for the aggregate trade regressions. The reason for this change in 
Table 4. Gravity model regression results using disaggregated export data

\begin{tabular}{|c|c|c|c|c|c|c|c|}
\hline & $\begin{array}{c}(1) \\
\text { Food \& } \\
\text { Beverages }\end{array}$ & $\begin{array}{c}(2) \\
\text { Industrial } \\
\text { Supplies }\end{array}$ & $\begin{array}{c}\text { (3) } \\
\text { Fuels \& } \\
\text { Lubricants }\end{array}$ & $\begin{array}{c}\text { (4) } \\
\text { Capital Goods }\end{array}$ & $\begin{array}{c}\text { (5) } \\
\text { Transport } \\
\text { Equipment }\end{array}$ & $\begin{array}{l}\text { (6) } \\
\text { Consumer } \\
\text { Goods }\end{array}$ & $\begin{array}{c}\text { (7) } \\
\text { Other Goods }\end{array}$ \\
\hline Multimodal Transport & $\begin{array}{c}-0.018^{* *} \\
(0.002)\end{array}$ & $\begin{array}{c}0.013 * * * \\
(0.000)\end{array}$ & $\begin{array}{c}-0.029 * * \\
(0.007)\end{array}$ & $\begin{array}{c}0.055^{* * *} \\
(0.000)\end{array}$ & $\begin{array}{c}0.049 * * * \\
(0.000)\end{array}$ & $\begin{array}{c}0.062 * * * \\
(0.000)\end{array}$ & $\begin{array}{c}0.048 * * * \\
(0.000)\end{array}$ \\
\hline $\log (\mathrm{GDP})$ & $\begin{array}{c}0.395^{* * *} \\
(0.000)\end{array}$ & $\begin{array}{c}0.988^{* * *} \\
(0.000)\end{array}$ & $\begin{array}{c}2.319^{* * *} \\
(0.000)\end{array}$ & $\begin{array}{c}0.942 * * * \\
(0.000)\end{array}$ & $\begin{array}{c}1.634^{* * *} \\
(0.000)\end{array}$ & $\begin{array}{c}0.455^{* * *} \\
(0.000)\end{array}$ & $\begin{array}{c}1.162 * * * \\
(0.000)\end{array}$ \\
\hline Log(Distance) & $\begin{array}{c}-1.684 * * * \\
(0.000)\end{array}$ & $\begin{array}{c}-2.146 * * * \\
(0.000)\end{array}$ & $\begin{array}{c}-4.277 * * * \\
(0.000)\end{array}$ & $\begin{array}{c}-2.324^{* * *} \\
(0.000)\end{array}$ & $\begin{array}{c}-2.624 * * * \\
(0.000)\end{array}$ & $\begin{array}{c}-2.689 * * * \\
(0.000)\end{array}$ & $\begin{array}{c}-1.127 * * * \\
(0.000)\end{array}$ \\
\hline Tariff Rate & $\begin{array}{c}-0.000 \\
(0.936)\end{array}$ & $\begin{array}{c}-0.009 \\
(0.549)\end{array}$ & $\begin{array}{l}-0.052 \\
(0.471)\end{array}$ & $\begin{array}{c}0.007 \\
(0.814)\end{array}$ & $\begin{array}{c}0.079 * * * \\
(0.000)\end{array}$ & $\begin{array}{c}0.074 * * * \\
(0.000)\end{array}$ & $\begin{array}{c}0.024 \\
(0.307)\end{array}$ \\
\hline APEC & $\begin{array}{c}3.441 * * * \\
(0.000)\end{array}$ & $\begin{array}{c}6.192 * * * \\
(0.000)\end{array}$ & $\begin{array}{l}-0.661 \\
(0.891)\end{array}$ & $\begin{array}{c}3.851 * * * \\
(0.000)\end{array}$ & $\begin{array}{l}3.662 * \\
(0.026)\end{array}$ & $\begin{array}{c}2.724 * * * \\
(0.000)\end{array}$ & $\begin{array}{c}12.522 * * * \\
(0.000)\end{array}$ \\
\hline Common Language & $\begin{array}{c}1.681 * * * \\
(0.000)\end{array}$ & $\begin{array}{c}0.071 \\
(0.697)\end{array}$ & $\begin{array}{l}-0.029 \\
(0.956)\end{array}$ & $\begin{array}{l}0.399^{*} \\
(0.030)\end{array}$ & $\begin{array}{c}0.211 \\
(0.477)\end{array}$ & $\begin{array}{c}0.647 * * * \\
(0.001)\end{array}$ & $\begin{array}{c}0.154 \\
(0.711)\end{array}$ \\
\hline Common Border & $\begin{array}{c}0.471 \\
(0.290)\end{array}$ & $\begin{array}{l}0.864^{*} \\
(0.019)\end{array}$ & $\begin{array}{c}1.223 \\
(0.151)\end{array}$ & $\begin{array}{c}0.456 \\
(0.226)\end{array}$ & $\begin{array}{c}0.513 \\
(0.351)\end{array}$ & $\begin{array}{c}0.350 \\
(0.395)\end{array}$ & $\begin{array}{l}1.963^{* *} \\
(0.010)\end{array}$ \\
\hline Common Colonizer & $\begin{array}{l}-0.575 \\
(0.330)\end{array}$ & $\begin{array}{l}-0.149 \\
(0.700)\end{array}$ & $\begin{array}{l}3.275^{*} \\
(0.015)\end{array}$ & $\begin{array}{l}-0.956 * \\
(0.037)\end{array}$ & $\begin{array}{l}-0.651 \\
(0.457)\end{array}$ & $\begin{array}{c}0.476 \\
(0.137)\end{array}$ & $\begin{array}{l}1.706^{*} \\
(0.035)\end{array}$ \\
\hline Colony & $\begin{array}{c}1.854 * * * \\
(0.000)\end{array}$ & $\begin{array}{c}1.956^{* * * *} \\
(0.000)\end{array}$ & $\begin{array}{c}0.969 \\
(0.446)\end{array}$ & $\begin{array}{l}1.619^{* *} \\
(0.001)\end{array}$ & $\begin{array}{c}2.018 * * \\
(0.002)\end{array}$ & $\begin{array}{c}2.098 * * * \\
(0.000)\end{array}$ & $\begin{array}{c}0.532 \\
(0.471)\end{array}$ \\
\hline Observations & 2306 & 2799 & 1023 & 2585 & 1825 & 2537 & 679 \\
\hline$R^{2}$ & 0.422 & 0.624 & 0.528 & 0.644 & 0.550 & 0.629 & 0.590 \\
\hline$\chi^{2}$ & $\mathrm{n} / \mathrm{a}$ & $\mathrm{n} / \mathrm{a}$ & $\mathrm{n} / \mathrm{a}$ & $5629.055^{* * *}$ & $\mathrm{n} / \mathrm{a}$ & $134301.896^{* * *}$ & $\mathrm{n} / \mathrm{a}$ \\
\hline Fixed Effects & Importer & Importer & Importer & Importer & Importer & Importer & Importer \\
\hline Random Effects & Exporter & Exporter & Exporter & Exporter & Exporter & Exporter & Exporter \\
\hline
\end{tabular}

Note: Dependent variable is $\log (1+$ Exports). Estimation is by GLS. Standard errors are robust, and adjusted for clustering by reporter. Prob. values are in parentheses below the coefficient estimates. Statistical significance is indicated by: $* 10 \%, * * 5 \%$, and $* * * 1 \%$. 
Table 5. Gravity model regression results using disaggregated export data (continued)

\begin{tabular}{|c|c|c|c|c|c|c|c|}
\hline & (1) & (2) & (3) & (4) & (5) & (6) & (7) \\
\hline & Food \&Beverag & es Industrial Supplies & Fuels \& Lubricants & Capital Goods & Transport Equipment & Consumer Goods & Other Goods \\
\hline \multirow[t]{2}{*}{ Maritime Transport } & $-0.021 * * *$ & $0.011 * * *$ & $-0.034 * * *$ & $0.029 * * *$ & 0.007 & $0.058 * * *$ & $-0.012 *$ \\
\hline & $(0.000)$ & $(0.003)$ & $(0.000)$ & $(0.000)$ & $(0.279)$ & $(0.000)$ & $(0.082)$ \\
\hline \multirow[t]{2}{*}{ Air Transport } & $0.067 * * *$ & $0.007 * *$ & 0.012 & -0.006 & $-0.013 * *$ & $0.012 * * *$ & $0.016^{* *}$ \\
\hline & $(0.000)$ & $(0.038)$ & $(0.198)$ & $(0.107)$ & $(0.010)$ & $(0.001)$ & $(0.012)$ \\
\hline \multirow[t]{2}{*}{ Land Transport } & $-0.069 * * *$ & -0.005 & $-0.043^{* * *}$ & -0.004 & $0.047 * * *$ & $-0.007 * *$ & 0.003 \\
\hline & $(0.000)$ & $(0.100)$ & $(0.000)$ & $(0.181)$ & $(0.000)$ & $(0.015)$ & $(0.611)$ \\
\hline \multirow[t]{2}{*}{ Logistics Competence } & $0.063 * * *$ & $0.009 * *$ & $0.037 * * *$ & $0.040 * * *$ & $0.011^{*}$ & $0.028 * * *$ & $0.065 * * *$ \\
\hline & $(0.000)$ & $(0.025)$ & $(0.003)$ & $(0.000)$ & $(0.078)$ & $(0.000)$ & $(0.000)$ \\
\hline \multirow[t]{2}{*}{$\log (\mathrm{GDP})$} & $-0.272 * * *$ & $0.926 * * *$ & $2.210 * * *$ & $1.109 * * *$ & $1.914 * * *$ & $0.353 * * *$ & $1.185 * * *$ \\
\hline & $(0.005)$ & $(0.000)$ & $(0.000)$ & $(0.000)$ & $(0.000)$ & $(0.000)$ & $(0.000)$ \\
\hline \multirow[t]{2}{*}{ Log(Distance) } & $-2.262 * * *$ & $-2.166^{* * *}$ & $-4.689 * * *$ & $-2.438 * * *$ & $-2.551 * * *$ & $-2.649 * * *$ & $-1.635^{* * *}$ \\
\hline & $(0.000)$ & $(0.000)$ & $(0.000)$ & $(0.000)$ & $(0.000)$ & $(0.000)$ & $(0.000)$ \\
\hline \multirow[t]{2}{*}{ Tariff Rate } & $0.010 * * *$ & -0.009 & 0.027 & 0.001 & $0.081 * * *$ & $0.074 * * *$ & $0.046^{*}$ \\
\hline & $(0.003)$ & $(0.522)$ & $(0.730)$ & $(0.978)$ & $(0.000)$ & $(0.000)$ & $(0.036)$ \\
\hline \multirow[t]{2}{*}{ APEC } & $3.386 * * *$ & $6.205^{* * *}$ & -0.788 & $3.807 * * *$ & $3.602 * *$ & $2.911 * * *$ & $12.738 * * *$ \\
\hline & $(0.000)$ & $(0.000)$ & $(0.877)$ & $(0.000)$ & $(0.014)$ & $(0.000)$ & $(0.000)$ \\
\hline \multirow[t]{2}{*}{ Common Language } & -0.077 & -0.035 & -0.760 & 0.181 & $0.555^{*}$ & $0.556 * * *$ & -0.329 \\
\hline & $(0.753)$ & $(0.858)$ & $(0.170)$ & $(0.348)$ & $(0.074)$ & $(0.003)$ & $(0.440)$ \\
\hline \multirow[t]{2}{*}{ Common Border } & 0.635 & $0.770 * *$ & $1.466^{*}$ & 0.302 & 0.698 & -0.075 & $2.005 * *$ \\
\hline & $(0.163)$ & $(0.036)$ & $(0.097)$ & $(0.431)$ & $(0.204)$ & $(0.849)$ & $(0.006)$ \\
\hline \multirow[t]{2}{*}{ Common Colonizer } & -0.896 & -0.296 & $3.380 * *$ & $-1.071 * *$ & -0.295 & -0.158 & $1.863 * *$ \\
\hline & $(0.133)$ & $(0.458)$ & $(0.013)$ & $(0.023)$ & $(0.732)$ & $(0.644)$ & $(0.021)$ \\
\hline \multirow[t]{2}{*}{ Colony } & $1.976 * * *$ & $2.041 * * *$ & 1.127 & $1.900 * * *$ & $1.789 * * *$ & $2.534 * * *$ & 0.374 \\
\hline & $(0.000)$ & $(0.000)$ & $(0.374)$ & $(0.000)$ & $(0.006)$ & $(0.000)$ & $(0.612)$ \\
\hline Observations & 2306 & 2799 & 1023 & 2585 & 1825 & 2537 & 679 \\
\hline$R^{2}$ & 0.505 & 0.626 & 0.541 & 0.652 & 0.559 & 0.656 & 0.614 \\
\hline$\chi^{2}$ & $\mathrm{n} / \mathrm{a}$ & $\mathrm{n} / \mathrm{a}$ & $\mathrm{n} / \mathrm{a}$ & $5497.932 * * *$ & $\mathrm{n} / \mathrm{a}$ & $163943.629 * * *$ & $\mathrm{n} / \mathrm{a}$ \\
\hline Fixed Effects & Importer & Importer & Importer & Importer & Importer & Importer & Importer \\
\hline Random Effects & Exporter & Exporter & Exporter & Exporter & Exporter & Exporter & Exporter \\
\hline
\end{tabular}


sample size is that not all economies trade all types of goods with all other economies. An additional problem with these regressions is that the BEC is a very broad classification that arguably groups together products that do not necessarily behave the same way in the context of trade and transport analysis. Future work could explore this point further by using a different classification system that is more homogeneous, such as ISIC.

\section{Conclusion and Policy Implications}

The gravity model has been a useful platform in exploring the links between multimodal transport connectivity and APEC exports. Taking the results from the modeling exercise together, we find strong evidence that multimodal transport matters for trade. Of course, different types of transport matter more for some sectors than others. Overall performance, however, is vital in most sectors-and this is particularly true for logistics competence, including the private sector's ability to manage complex international transactions that involve multimodal linkages.

The gains from reform in multimodal transport are potentially significant. The APEC region would increase exports by around $4 \%$, or between $2 \%$ and $6 \%$ per member economy. In dollar terms, this equates to an impact gain of $\$ 500 \mathrm{bn}$ or between $\$ 850 \mathrm{~m}$ and $\$ 115 \mathrm{bn}$ per member economy. Economies that are open, highly integrated into world markets, and with strong multimodal connectivity stand to gain even more.

Future research could extend our results in a number of ways. First, as new data become available, it will be possible to improve the gravity model specification by using panel data techniques. This approach will make it possible to ensure that a wider range of external influences are excluded from the model, and thus support the robustness of our results.

Second, connectivity in individual transport modes could be assessed using network analysis methods. The advantage of using network analysis is that such techniques capture the importance of an economy's position in the international transport system, not just the quantity and quality of its infrastructure and logistics performance. However, the data for undertaking this type of analysis are not yet widely available, and appropriate methodologies are still being developed. Data requirements include detailed geographical and frequency information on individual sea, air, and land routes. For sea and air connectivity, data can be 
extracted from industry sources. For land connectivity, use of geographical information systems modeling (GIS) is required. At the present time, this work has only been done for a small number of specific regions regarding land transport (e.g., Shepherd and Wilson, 2007, for Eastern Europe and Central Asia).

Third, it will be important to undertake detailed cost-benefit analysis of individual reform projects. Improving multimodal transport performance often requires substantial investments in infrastructure, with real economic costs. The balance is generally positive, but each project needs to be evaluated on its own merits.

In addition, at least four sets of policy implications flow from our findings.

First, infrastructure remains a key constraint in some member economies. Investing in trade- and transport-related infrastructure such as ports, airports, road, and rail links should remain a priority. Mobilizing finance for such investments can be challenging in the wake of the Global Financial Crisis, and there may be scope for economies to work together on a regional or sub-regional basis to help overcome these constraints. Facilitating trade through regional transit corridors can also be beneficial. Private-public partnerships can be a key component in building and upgrading infrastructure, as well as ensuring an appropriate level of maintenance over time (see below). This is a topic being discussed under the purview of APEC's Senior Finance Officials Meeting (SFOM).

Second, it is important to set funds aside for infrastructure maintenance in addition to construction. Depreciation of roads and other infrastructure tends to diminish their usefulness - and their trade effects-over time. Continuous upgrading is necessary. The return from investment in infrastructure maintenance can be very high, but setting up sustainable maintenance systems is a challenge for many economies.

Third, a supportive regulatory environment can help improve multimodal transport connectivity. A more liberal air transport environment is one way of boosting overall air transport performance. Recent work by the World Bank similarly suggests that a more liberal regulatory environment in distribution services helps promote higher quality logistics services (Arvis et al., 2010). Regulatory reform based on rigorous cost-benefit analysis can clearly have major economic benefits in this area. The private sector should of course be involved as far as possible in the regulatory reform process. The real economic costs of designing and implementing regulatory reform are very small compared with infrastructure investments, although the political economy constraints can be 
significant. Nonetheless, they may represent "low hanging fruit", in the sense of large gains that can be acquired relatively inexpensively. This is not to understate the technical complexity of reform, however. A whole supply chain approach means paying attention to the full range of regulatory, contractual, and competition policy issues that arise. ${ }^{5}$ Coordination among the various actors is vital.

Finally, private sector development is also a key element of improving multimodal transport connectivity. Indeed, it may even be the most important part of the overall reform agenda. Our research shows that the quality and competence of private logistics services can have a stronger effect on trade performance than the other areas of multimodal transport examined here. Building human and financial capacity in the logistics sector should remain a priority for member economies. So too should involving the private sector in infrastructure upgrading, maintenance, and regulatory reform. Civil society is an important partner in these processes, and appropriate involvement can help ensure adequate information flows to governments, as well as create an environment of positive compliance and partnership.

Received 15 November 2010, Revised 7 Septmber 2011, Accepted 10 Septmber 2011

\section{References}

Anderson, J.E. \& Van Wincoop, E. (2003), Gravity with gravitas: a solution to the border puzzle. American Economic Review, 93(1), 170-192.

Anderson, J. \& Van Wincoop, E. (2004), Trade costs. Journal of Economic Literature, 42(3), 691-751.

APEC Transportation Working Group, and the Australian Department of Transport and Regional Services, 2007. Liberalization of air services in the APEC region, 19952005. Prepared by the Centre for Asia Pacific Aviation.

Arvis, J.-F., Mustra, M., Ojala, L., Shepherd, B., \& Saslavsky, D. (2010), Connecting to compete 2010: Trade logistics in the global economy. Washington, D.C.: The World Bank.

Bafoil, François. (2010), Relooking at the role of transport infrastructure in trade, regional growth and governance: comparing Greater Mekong Subregion (GMS) and Central Eastern Europe (CEE). In: EU Centre Research Seminar. Singapore, 5 May 2010.

Baier, S., \& Bergstrand, J. (2009), Bonus Vetus OLS: a simple method for approximating international trade cost effects using the Gravity Model. Journal of International

${ }^{5}$ The experience of the Australian Competition and Consumer Commission is instructive in this regard: Samuels (2010). 
Economics, 77(1), 63-76.

Battaglia, Paul. (2007), Modeling intermodal transportation for developing countries. In:

The First European Conference on Management of Technology (EuroMOT), 2006.

Available at: http://www.iamot.org/conference/index.php/ocs/9/schedConf/presentations [Accessed April 2010].

Buys, P., Deichmann, U., \& Wheeler, D. (2006), Road network upgrading and overland trade expansion in Sub-Saharan Africa. Policy Research Working Paper, No. 4097, The World Bank.

Chaney, T. (2008), Distorted Gravity: the intensive and extensive margins of international trade. American Economic Review, 98(4), 1707-1721.

Carruthers, Robin, Bajpai, Jitendra N., \& Hummels, D. (2003), Trade and logistics in East Asia: a development agenda, EASTR Working Paper, No. 3, Transport Sector Unit, Infrastructure Department, East Asia and Pacific Region, The World Bank.

The Central Intelligence Agency. (2009), CIA World Factbook. Online. Available at: https://www.cia.gov/library/publications/the-world-factbook/index.html [Accessed 11 December 2009].

Geloso-Grosso, M., \& Shepherd, B. (2009), Liberalizing air cargo services in APEC. GEM Sciences Po. Working Paper.

Guerrero, P., Lucenti, K., \& Galarza, S. (2009), Trade logistics and regional integration in Latin America \& the Caribbean. Inter-American Development Bank working paper series. 148. Available at: http://idbdocs.iadb.org/wsdocs/getdocument.aspx?docnum= 35031936 [Accessed March 2010]

Helpman, E., Melitz, M. \& Rubinstein, Y. (2008), Estimating trade flows: trading partners and trading volumes. Quarterly Journal of Economics, 123(2), 441-487.

Hoekman, B. \& Nicita, A. (2008), Trade policy, trade costs, and developing country trade. Policy Research Working Paper, No. 4797, The World Bank.

Hummels, D., Minor, P., Reisman, M., \& Endean, E. (2007), Calculating tariff equivalents for time in trade. Available at: http://www.tcboostproject.com/_resources/resource/ Calculating\%20Tariff\%20Equivalents\%20for\%20Time\%20in\%20Trade.pdf [Accessed March 2010].

Jacoby, David \& Hodge Daniel. (2008), Infrastructure investment: the supply chain connection. CSCMP's Supply Chain Quarterly, Q4.

Limao, N., \& Venables, A. (2001), Infrastructure, geographical disadvantage, transport costs, and trade. World Bank Economic Review, 15(3), 451-479.

MIGA (The Multilateral Investment Guarantee Agency). (2003), Benchmarking FDI competitiveness in Asia, Snapshot Asia. Washington DC: The World Bank Group/ MIGA.

Prentice, Barry E. (2003), Importance of intermodal connectivity and bottleneck elimination. In: Canadian Transportation Research Forum (CTRF) $38^{\text {th }}$ Annual Conference.

Samuels, G. (2010), How competition law supports transport and logistics solutions. In: Australian Logistics Council Forum, Sydney, 2010. Available at: http:/www. 
accc.gov.au/content/item.phtml?itemId $=916863 \&$ nodeId $=2 \mathrm{a} 3 \mathrm{afb} 3 \mathrm{faf} 8 \mathrm{da} 3 \mathrm{cce} 01 \mathrm{~d}$ 782c701882c7\&fn=How [Accessed 27 April 2010].

Shepherd, B. (2010), Trade facilitation in APEC and ASEAN: Delivering the Goods? Working paper, http://ideas.repec.org/p/pra/mprapa/21531.html.

Shepherd, B., \& Wilson, J. (2007), Road infrastructure in Europe and Central Asia: does network quality affect trade? Journal of Economic Integration, 22(4), 723-747.

Silva, J.M.C.S., \& Tenreyro, S. (2006), The log of Gravity. Review of Economics and Statistics, 88(4), 641-658.

UNCTAD. (2009), Liner shipping connectivity in 2009. UNCTAD Transport Newsletter, 43(2/3), 6-10.

Vickerman, Roger. (2007), Gateways, corridors and competitiveness: an evaluation of TransEuropean networks and lessons for Canada. In: University of British Columbia, Center for Transportation Studies, Roundtables and International Conference. May 2007.Available at: http://www.gateway-corridor.com/roundconfpapers/papers.htm [Accessed March 2010].

Wilmsmeier, G., \& Hoffmann, J. (2008), Liner shipping connectivity and port infrastructure as determinants of freight rates in the Caribbean. Maritime Economics and Logistics, 10, 130-151.

Wilson, J., Mann, C. \& Otsuki, T. (2005), Assessing the benefits of trade facilitation: a global perspective. The World Economy, 28(6), 841-871.

World Bank. (2009), World development report 2009: reshaping economic geography. Washington DC: The World Bank. 